Claremont Colleges

Scholarship@ Claremont

All HMC Faculty Publications and Research

HMC Faculty Scholarship

$11-1-2010$

\title{
Teaching Research: Encouraging Discoveries
}

Francis E. Su

Harvey Mudd College

\section{Recommended Citation}

Francis Edward Su. Teaching Research: Encouraging Discoveries. Amer. Math. Monthly, 117:159-169, 2010.

This Article is brought to you for free and open access by the HMC Faculty Scholarship at Scholarship @ Claremont. It has been accepted for inclusion in All HMC Faculty Publications and Research by an authorized administrator of Scholarship @ Claremont. For more information, please contact scholarship@cuc.claremont.edu. 


\title{
Teaching Research: Encouraging Discoveries
}

\section{Francis Edward Su}

\begin{abstract}
What does it take to turn a learner into a discoverer? Or to turn a teacher into a co-adventurer? A handful of experiences - from teaching a middle-school math class to doing research with undergraduates - have changed the way that I would answer these questions. Some of the lessons I've learned have surprised me.
\end{abstract}

The title of this article may seem a little puzzling. After all, the words teaching and research usually only appear in the same sentence when separated by the word and, on a list of a faculty member's obligations. Do these words belong together at all? What does teaching have to do with research or discovery?

One of my favorite quotes about teaching comes from one we normally associate with research:

The principal aim of mathematical education is to develop certain faculties of the mind, and among these intuition is not the least precious. It is through it that the mathematical world remains in touch with the real world.

—Henri Poincaré [5, p. 128]

But Poincaré also said:

It is by logic that we prove, but by intuition that we discover.

-Henri Poincaré [5, p. 129]

So we teach to build intuition, and intuition enables our students to make discoveries. Notice that Poincare does not say that the principal aim of teaching is to convey facts or theorems. The principal aim of mathematical teaching is to build qualities of mind that enable students to make discoveries.

But how does one do that? How does one turn a learner into a discoverer? When I was first starting out as a new professor, I might have given these answers:

- Teach the needed background.

- Cultivate maturity.

- Inspire them!

- Ask good questions.

- Select the smartest students.

- Give open problems.

- Advertise the thrill of research.

- Be an expert in what you advise.

- Encourage independence.

doi:10.4169/000298910X521634

This article is based on the James R. C. Leitzel Lecture, delivered by the author at the MAA MathFest, Knoxville TN, on Friday, August 11, 2006. 
Now, I shall explain why I believe every one of these pieces of advice is either plainly wrong or, at best, inadequate. Along the way, I will mention some concrete teaching ideas that you may find useful as well.

1. THE PRINCIPAL AIM OF MATHEMATICAL TEACHING. There is one word that is an excellent metaphor for everything I want to say:

\section{YAWP.}

What is a yawp?

I sound my barbaric yawp over the roof(top)s of the world!

—John Keating, quoting a Walt Whitman poem, in the movie Dead Poets Society

As Keating explains, a yawp is a loud cry or yell. But in the poetry of Walt Whitman, the word yawp refers to the inner groaning inside each of us, too deep for words, that is yearing to be expressed and experienced. In the movie Dead Poets Society, an English teacher named John Keating (played by Robin Williams) does more than just teach poetry - rather, he breathes poetry, he inhabits poetry, and he inspires his students to do the same. In one scene, his student Todd Anderson (played by Ethan Hawke) has been struggling all weekend to write a poem, but without success. In class, when Todd fails to deliver a poem, Keating encourages Todd to first find his yawp, and once he does, Keating helps him transform his yawp into poetry in a truly mesmerizing manner [6, 55:07-57:57].

Keating was an exuberant teacher who exhorted his students to live extraordinary lives. He did not measure this by the usual metrics of success and accomplishment; rather, for Keating, living extraordinarily meant becoming who they were created to be: human beings empowered to express their passion through poetry, and to use their souls, spirits, hearts, and minds to seize the day with all its wonders.

As mathematicians, we have experienced one of the greatest human wonders: the thrill of discovery. And the aesthetic pleasure of an elegant proof captures our spirits just as poetry does. So what I seek to cultivate in my students is a mathematical yawp:

Definition. A mathematical yawp is that expression of surprise or delight at discovering the beauty of a mathematical idea or argument.

Every student is capable of a mathematical yawp. The yawp may not be a poem when it is first expressed, but I believe the principal aim of mathematical teaching is to nurture the mathematical yawp, and help transform it into poetry.

2. MATH FUN FACTS. When I first began teaching calculus in graduate school, I lamented the fact that most students would leave college with a mistaken notion of what mathematics is. After all, most of them took math to fulfill a requirement, usually some brand of calculus or something less advanced, and it was the final course they would take. As a result, the view most students develop of mathematics is that it a cut-and-dried, 400-year-old list of theorems and applications. They do not get the sense that mathematics is an exciting, living, and developing subject.

I wanted to change that impression. So I began to present daily "Fun Facts," by taking 5 minutes at the start of each lecture to show my students some mathematical idea that I thought was fascinating - for instance: the uncountability of the reals, the 
nine-point circle, tiling a chessboard with opposite corners removed, the ham sandwich theorem, etc. The facts I chose usually had nothing to do with calculus; the main point was to broaden their perspective of mathematics, to show them math is alive and full of interesting questions and new ways of thinking, and to whet their appetite for learning more.

The student reaction was overwhelming. They loved Fun Facts. They clamored for them at the beginning of every class. Students stopped coming late! If I ever forgot to do a Fun Fact, they would remind me of my obligation, as if going through Fun Fact withdrawal. Sometimes they would clamor for more than one (though perhaps to postpone the calculus lecture). I had nurtured their mathematical yawp.

And they yawped for more. They would often come back to me with questions about Fun Facts, or variants of Fun Facts they had studied or solved. Many of my teaching evaluations cited Fun Facts as a reason that they wanted to take more math, even if they didn't like calculus. I had helped them find their yawp, even if it wasn't for calculus!

And then it dawned on me that it was more important to nurture their yawp than to teach them calculus.

\section{Lesson \#1. Teach the needed background? No. Nurture the yawp.}

Of course, we hope that these goals are in harmony, but if there is ever a conflict, we must remember the principal aim. For instance, I make it a policy never to stop nurturing the yawp in favor of "getting through the material."

If you'd like to try using Fun Facts in your courses, I have created a website and iPhone application containing two hundred Fun Facts that I have used. (See [7] or Google "Math Fun Facts" to find it.) But the best Fun Facts are the ones that you care about the most! Give your students the Fun Facts that fueled your passion for mathematics!

3. WHAT I LEARNED FROM 8TH GRADERS. I found a way to use a similar idea in the K-12 arena. One of the most formative experiences of my career occurred in my second year as a faculty member, when I learned that a principal of a local middle school was looking for a professor to teach a math enrichment course to challenge some bright 8 th graders. Intrigued by the idea, I agreed.

Once a week, the 8th grade math class at this school was divided into two groups by ability. One half stayed with the usual teacher to get some needed help and extra practice, and the other group met with me.

What should I do with them? Instead of teaching them more of the same stuff that they might encounter again in high school, I chose instead to teach them "enrichment material," such as extended Fun Facts, proof techniques like induction and contradiction, fast mental arithmetic, magic tricks using mathematical ideas, elementary knot theory and Reidemeister moves, mind-boggler puzzles, elementary combinatorics, etc.

Many things about this experience surprised me. First of all, teaching 8th graders is a lot harder than teaching college students! Any issue related to teaching college students is amplified for 8th graders. If college students can't sit still for more than fifteen minutes, 8th graders can't sit still for five. College students get bored; 8th graders noticeably fidget in their seats. College students give nodding winks at each other; 8th graders pass notes. If college men speak up in class more than college women, 8th grade boys dominated my class discussions entirely.

As a result, for everything I would normally do to engage a college class, I had to do better with these 8th graders. If my college teaching style is interactive, my 
8th grade teaching style had to be more so. I had to pay more attention to domineering students, give more reassurance and encouragement, repeat ideas more often, ask more questions to keep them engaged and ignite their curiosity and imagination ... and it occurred to me that doing these things was great for my college teaching!

\section{Lesson \#2. Cultivate maturity in your students? No. Restore their child-like curiosity and imagination.}

I believe there isn't a single concept in a first-year college course that an 8th grader couldn't understand if developed well. So what will you do to develop it well, to engage your students?

We must find ways to restore the child-like curiosity of college students. I see that 8th graders are more curious, more willing to probe with a "why?," more willing to ask questions if they don't understand, and more willing let you know your pen is leaking in your front pocket. Somewhere along the path to adulthood, they lose the ability to ask questions.

Was this enrichment class a success? Did they develop a mathematical yawp? For end-of-term evaluations, I asked these 8th grade students to complete the following sentence:

I now know that mathematics is ...

I received some responses like this:

- ... harder than I thought (I thought it was too easy before).

But most of the responses were like these:

- ... extremely challenging, yet excessively fun. Also, it's a much broader topic than I had originally thought.

- ... can be fun and not always so boring. I also now know that sometimes, mathematics can have absolutely nothing to do with numbers.

- ... a broader subject than it was to me before; this class opened up many new, exciting, and challenging topics that have made me more interested in mathematics as a whole.

- ... a world of mysteries waiting to be discovered.

Exactly! We seek to build intuition to enable them to make discoveries!

Recently, I heard from a student in this class who is now just graduating from college, eight years later. He said: "from what I remember I really enjoyed it . . . in middle school it was the only class that really opened my eyes to different thinking." All these responses indicate that they had developed a yawp.

Another lesson I learned from this class was how easy it was to miss hearing a yawp. There was a shy girl in this class who hardly ever spoke up and seemed not to be engaged at all. I didn't notice her for several weeks until I assigned some homework on induction. I was curious to see what 8th graders could do, and I naively expected the best students to be the ones who were answering all the questions.

By and large, the students seemed to grasp induction. But I'd say the homeworks looked like the typical work you would get from beginning calculus students, not so good on the form and very unclear in the writing. On the other hand, this student's induction proof was astounding. It had perfect form, perfect understanding, perfect 
writing - in complete sentences with good connective phrases, journal style, with the clarity and maturity that I expect from professional mathematicians.

Throughout the term she continued to impress me, always in her quiet way. What was interesting to me was that her regular 8th grade math teacher did not seem to think she was exceptional at all! Why?

And then I wondered how many students like her I was missing in my college courses because of the way I was teaching, and what I could be doing to look for their yawp.

\section{Lesson \#3. Identify invisible yawpers.}

As a sad footnote, after the class was over, I told this student's parents that if she should show an interest in math later on, they should encourage it because she was truly exceptional. Their reaction (or lack thereof) was as if to say: why would I want my girl to study math? And I understood then that there are still social pressures that push children out of callings for which they might have a gift.

4. NURTURING POETS. I surveyed a dozen of my former thesis and research students and asked them to reflect on their experiences doing research as undergraduates, whether with me or in other settings. I refer to them as Poets, since they have found their yawp. Nearly all of them are now in graduate school or just beyond.

One question I asked them was what early influences caused them to think research in mathematics was something they wanted to try. One Poet said:

My parents were a huge influence on me, posing mathematical questions to me when I was young ... for example, I remember my dad asking me how many steps it would take to get to the wall if on each step, I went halfway.

She had found her yawp because her parents nurtured it by asking probing questions, but they let her experience the joy of discovery herself.

More than half the students cited the experience of working puzzles or doing math problem-solving as early influences. Many had been part of organized problem-solving groups, or at summer math programs where they, in the words of one Poet, "caught a fever of math research." In effect, these groups became their "Dead Poets Societies," places and spaces where they could gather to recite poems and yawp together.

At Harvey Mudd College, Andy Bernoff and I run a problem-solving seminar that has become something of a phenomenon on campus. Every fall, about 70 students (that's 10 percent of our student body!) gather on Tuesday nights over pizza to have fun with problem-solving. We keep the atmosphere lively, and we allow them to work in groups. We introduce a few problem-solving techniques at the start, then let them work on a slate of five or six problems, break for pizza, then we have students present their solutions $[\mathbf{1}, \mathbf{2}]$. They have the space to make discoveries themselves, and by letting them present their solutions, we give them the space to yawp as well (just as any good Dead Poets Society would do).

This seminar now attracts a large fraction of students who are not even math majors, but who come for the thrill of yawping, either when they solve the problems, or when they see a solution and get the "aha!" experience that is at the heart of a true yawp.

Would I still say it is important to inspire students? Of course. But I think it is even better to give students space for self-inspiration so they can experience and express their yawp. 


\section{Lesson \#4. Inspire them? \\ Better: create spaces for self-inspiration.}

Moore-method courses are another example of spaces where students can find their yawp and make discoveries themselves. I won't say much about them here, because much has been said about them, but the best course I ever took as an undergraduate was a Moore-method topology course (taught by Mike Starbird) and it had a profound impact on developing my yawp.

We all understand how important it is for a professor to ask good questions of her students. After all, a good question can prompt a discovery. But I now believe it is even better if you can teach students how to ask good questions themselves!

\section{Lesson \#5. Ask good questions? \\ Better: teach how to ask good questions.}

Let me give you an example that I learned from my colleague Lesley Ward. She has used "question stems" in her courses, to teach students how to ask good questions (using a suggestion of T. J. Mueller, and adapting questions from [3]). For instance, in an analysis course, after giving part of a lecture on some topic, she asks students to form groups and she hands out cards which have questions like these on them, with blanks:

- What is an example of ...?

- How does ... affect... ?

- What would happen if ... ?

- What is the difference between ... and ... ?

The students formulate questions about the lecture based on these models, and then they discuss them in class. In addition to the benefit of teaching students the kinds of questions they might think about, it has the added benefit of students often answering each other's questions!

Another way of encouraging students to ask good questions is to reward them for it. On some exams, I put a problem in which I ask students to write down a research question that they would like to answer, based on what they have learned so far in the class. The answer to the question doesn't have to be unknown to the world, it just has to be unknown to them. I am happy if they have just gone through the reflection necessary to ask a question, so I give full credit for any reasonable attempt at formulating a question.

For our students to experience true research, we should certainly give them open problems. But in order to cultivate a yawping ability, I believe it is much better to give students open-ended problems.

\section{Lesson \#6. Give open problems? \\ Better: give open-ended problems.}

I learned a terrific example of this from my colleague Michael Orrison, who has developed a project that he has used successfully in a discrete mathematics course. In it he asks students to:

Define a measure of the complexity of a graph. Compute it for several examples, and prove some properties about your measure. 
This is the main idea; you can find more details in [4]. What is great about this exercise is that it is open-ended, and there are multiple right answers. Students are able to be creative about the solution, and they are excited about investigating a concept that they have defined themselves. At the end of the project, students make presentations.

Looking at some of the slides from past presentations, one sees that students develop a wide variety of notions of complexity. More interestingly, they find creative ways of expressing their ideas, e.g., by describing their complexity measure as answers to questions: "How expensive is it to plow the town?," "How many friends do you have?," etc.

And their yawps are often visible as they explore properties of their measures of complexity-for instance, written on one recent memorable slide, a student exclaims "Really Cool!" and "Yowza!" when she realizes that her measure is invariant under taking graph complements. That's a yawp if I ever saw one!

My colleague Darryl Yong has even adapted Orrison's project as an exercise for high school teachers, in a conference called "Imagine Math Day" $[8,9]$. And there are many other project examples that could follow a similar model. For instance, "What is a fair voting procedure?" or "Define a measure of a center of a distribution." Last summer, I gave a couple of my research students the following open-ended problem: "List 10 generalizations of convexity." After they came up with those ten, I asked them to focus on the most interesting ones and try to characterize those notions of convexity in terms of properties that people already understand. My students had a lot of fun generating their list, and eventually took one of their notions and proved necessary and sufficient conditions that would allow someone to tell if a set satisfied their notion of convexity. This resulted in a paper that they wrote completely on their own, and submitted for publication. Because of one open-ended problem, they created a new idea, and they were motivated to study it and explore it-they yawped!

5. RESEARCH WITH UNDERGRADUATES. But now suppose you have taken your students to the point where they can yawp. How do you help them turn it into poetry? If a yawp is the thrill of discovery, a poem is a yawp that is communicated well. This is where the undergraduate research experience can play a big role.

One major question that every advisor faces is the question of how to choose students. I always thought that the best metric for this was to choose students who were the smartest, or got the best grades. However, I now think that something else is much more important—strong motivation and persistence.

\section{Lesson \#7. Select the smartest students? Not necessarily; select motivated students!}

One of the best research students that I have ever had was not a student that fit the mold of getting the best grades, and I did not notice her abilities from her coursework. She was a $B+$ student, and when she approached me about summer research I had already offered my research positions to other students. But she came back several times to ask, so I finally decided to go out of my way to ask the dean for extra funds to support her, and he agreed.

This was one of the most rewarding experiences that I have had as an advisor. The persistence my student showed in inquiring about research opportunities translated into a tenacity in tackling research problems. She was extremely dedicated and motivated, and always came to research meetings having done everything that we discussed at the last meeting, and more. She was the kind of student who was meticulous and took her time to carefully think things out, and so while taking exams was not a place 
where her gifts were displayed, she really shone in research problems where persistence and meticulousness are rewarded. And she was an excellent writer. By the end of the summer, she had completed a paper that was polished and ready to submit!

So, if I had to give advice about what to look for in a research student, I would say smarts are important, but if you have to choose between a super-smart student and a smart motivated student, I would go for the latter. Some qualities to look for: Are they persistent? Do they excel in something that shows dedication? For instance, we have a couple of undergraduate research students in our department this summer who are $B$ students, but one is a nationally-ranked player in the computer game StarCraft, and another is a hackey-sack expert. And their advisors report that these students are doing outstanding, publishable research.

Another question I ask about potential research students is: do they write well? I ask for a writing sample, such as a proof they have written for a homework exercise. Even if you don't choose a student who can write, it is nice to know what kind of writer you are working with. Such information can be useful, for instance, if you are choosing students to work in teams.

\section{Lesson \#8. Advertise the thrill of research? Better: set complete expectations.}

I used to want my research students to think research was going to be really fun and exciting. But now, I think that they should be aware of the whole picture. I now tell my students in advance that research can be frustrating at times, and I warn them that often it hits about the fourth week of the summer when they are really wrestling with their research problem. If I tell them in advance, then they aren't surprised when it happens, and they understand it is normal to feel that way.

Along these lines, one Poet says:

The most valuable aspect, in retrospect, was how my research jobs made researching look far less glamorous than I had thought it might be ... in a way it was demoralizing, but you likely want your bubble burst before you chase the dream too far.

But the same student also notes that understanding the expectations doesn't diminish his desire to yawp - he says: "The hope of delightful discoveries and taking part in that same cool elegance I recognized so long ago is still a large part of what keeps me going."

I also set clear expectations for my students about how to conduct their research. For instance, I ask them to keep track of what they are doing in a research notebook. I explain that this notebook is where they write down ideas that they want to follow through with later. I also tell them to start writing often and early in the process. When they get stuck or bored with thinking about their problem, they can write down what they have been doing, or learn LaTeX and LaTeX their work. Another Poet reports:

One of the best things I learned was organization ... especially since none of my later advisors mentioned this at all.

We can teach undergraduates research skills that will be useful to them later, even if, as the Poet suggests, graduate schools don't teach those same skills.

In advising research students, I always had the impression that you should be an expert in what you advise. After all, I think it is common for us to worry: how can we 
nurture a yawp in someone else if we don't know how it is we yawp ourselves? But now I think differently.

\section{Lesson \#9. Be an expert in what you advise? No, let the student be the expert.}

What do I mean by this? I think it is extremely important to give my student ownership of the problem. I tell my students at the start of the summer: "By the time the summer is over, you will be the local expert on this problem. You will know more than anyone else here about this problem, including me." Doing so gives them the excitement of living up to that challenge, and my job the rest of the summer is to probe, and model asking good questions (rather than trying to give them all the answers that I obviously don't yet have). So they are on an adventure to find out more than anyone else in my local neighborhood about their topic, and, by accompanying them on this journey, always asking or suggesting (but never forcing) where to go next, I am a "co-adventurer" with them. I listen to their yawps on this journey.

Not surprisingly, my research with students has taken a random walk through many fields; as an example, our papers have been published in a diverse collection of journals: Random Structures and Algorithms, Journal of Combinatorial Theory Series A, Discrete and Computational Geometry, Journal of Mathematical Analysis and its Applications, American Mathematical Monthly, and Journal of Mathematical Biology, among others.

In all these examples, I was never the expert on these topics, but I picked up what I needed to know in a journey with my students, often with the students teaching me. I am only a co-adventurer. Students also learn from this journey that research often involves learning many new and unfamiliar things.

6. BUILDING COMMUNITY. One of the biggest pieces of advice that I hear about advising research is the adage about encouraging students to be independent. While I believe this should be true much later in the research process, I strongly disagree with this in the early stages.

\section{Lesson \#10. Encourage independence? No! Give close guidance, and build community.}

For instance, I think it is very important to meet often and regularly, especially in the beginning of the research process. During those meetings, one should always set goals for the research students to work on for the next meeting. Doing so gives them something concrete to do and to report on and gives structure to the following meeting. It is especially important to have students write something up for each meeting. Doing so refines their thinking, and focuses discussion.

When it comes time to write a real paper, I always sit down with my student in front of the computer and write, together with the student, at least a few pages. This not only helps get the paper off the ground, but doing so also models for the student the process of writing. Students are often initially surprised by the care which I take to get definitions right, to make notations consistent, or to ensure that attributions about prior work are correct. They get to see how I think about writing and they can begin to do the same.

Throughout their research, I want my students to see that mathematics really is a social enterprise. We, as a community, decide what's important, our work depends on the work of others, and we work together with others to advance the field. In one 
project, I included an undergraduate student on a project that I was doing with an economist in Germany. I included my student in all the meetings (some by phone and some when my collaborator visited). By being fully part of this process, she was able to see one way in which collaboration could work, as well as see in this social setting how important it is to learn to communicate ideas well.

Poets report:

- My research experience definitely helped me learn about writing papers, and perhaps more importantly, about working with others to co-write papers.

- Working with other people besides you demonstrated the different possibilities when people with different strengths collaborated.

- Working with another person on a research question is fundamentally different than any of the other group work I had been exposed to.

I want students to see the importance of building community in their mathematical work. I hope that they can see that through collaboration, they can really have a lot of fun yawping together, whether that be through the sweat of persisting through a problem or the joy of actually solving it. As the Swedish proverb goes:

A joy shared is twice the joy. A sorrow shared is half the sorrow.

To summarize, how would I answer the question: How do you turn a learner into a discoverer?

- Nurture the yawp.

- Restore child-like curiosity and imagination.

- Identify invisible yawpers.

- Create spaces for self-inspiration.

- Teach how to ask good questions.

- Select motivated students.

- Give creative, open-ended problems.

- Set complete expectations.

- Let the student be the expert.

- Give close guidance, and build community.

John Keating did not teach his students poetry; he helped them yawp, he helped them inhabit the verse. He encouraged playful child-likeness. He created the space for his students to self-inspire in a resurrected Dead Poets Society, even though he himself never attended a meeting. He taught them how to find good subjects for poems. He engaged the students who were motivated, who had ears to hear. He encouraged creativity, and he encouraged community.

Let's help our students find their yawp and transform it into poetry.

ACKNOWLEDGMENTS. I thank Art Benjamin, Jon Jacobsen, Susan Martonosi, Claus-Jochen Haake, Ulrike Ervig, Mike Starbird, and Bruce Palka for their advice in preparing the Leitzel Lecture. I gratefully acknowledge NSF Grants DMS-0301129 and DMS-0701308 for supporting my research with undergraduates.

DEDICATION. This article is dedicated to: Jim Leitzel and Christine Stevens, co-founders of Project NExT, who have nurtured the professional development of more than a thousand mathematicians and given them places and spaces to yawp; and to Michael Moody, who will always be my Keating-O captain, my captain! 
1. A. J. Bernoff and F. E. Su, PCMI problem-solving references and resources (2003-2009), available at http://www.math.hmc.edu/〜ajb/PCMI/problem_solve.html.

2. — - Putnam, pizza \& problem-solving, Math Horizons (Sept 2004) 8-9.

3. A. King, Inquiry as a tool in critical thinking, in Changing College Classrooms, D. F. Halpern, ed., JosseyBass, San Francisco, 1994, 13-38.

4. M. Orrison, Graph complexity, in Resources for Teaching Discrete Mathematics: Classroom Projects, History Modules, and Articles, B. Hopkins, ed., MAA Notes \#74, Mathematical Association of America, Washington DC, 2009, 159-161.

5. H. Poincaré, Science et méthode, E. Flammarion, Paris, 1908; English trans. F. Maitland, Science and Method, T. Nelson, New York, 1914.

6. T. Shulman, Dead Poet's Society (dir. Peter Weir), Walt Disney Studios Home Entertainment, Burbank, CA, 1989.

7. F. E. Su, Math Fun Facts (1999-2010), available at http://www . math.hmc . edu/funfacts/.

8. D. Yong, Imagine Math Day (2009), available at http://www . math.hmc. edu/pdo/imd/.

9. D. Yong and M. Orrison, Imagine Math Day: Encouraging secondary school students and teachers to engage in authentic mathematical discovery, MAA Focus 30(6) (2008) 24-27.

FRANCIS EDWARD SU earned his B.S. in mathematics at the University of Texas, and his Ph.D. at Harvard under the direction of Persi Diaconis. He is now Professor of Mathematics at Harvey Mudd College. His research mixes geometry, topology, combinatorics, and applications to the social sciences, and he has coauthored numerous papers with undergraduates. He has a passion for popularizing mathematics; his Math Fun Facts website gets over a million hits each year. From the MAA, he received the 2001 Merten M. Hasse Prize for his writing and the 2004 Henry L. Alder Award for his teaching. He currently serves as First Vice-President of the MAA. In his spare time, he enjoys songwriting and gardening and is active in a Christian community where he can just be himself-passion not stifled by expectation, worth not derived from accomplishments. Department of Mathematics, Harvey Mudd College, Claremont CA 91711 su@math.hmc.edu 